\title{
HANG TUAH IN THE SEA OF ORAL MALAY NARRATIVES
}

\author{
Muhammad Haji Salleh \\ mhs0042@gmail.com \\ School of Humanities \\ Universiti Sains Malaysia
}

\begin{abstract}
Hang Tuah is a culture hero who defines both himself and the Malays, along with their feudal and universal values. Three forms of existences have been bestowed on him by the peoples of the Malay Archipelago, i. e. the historical, the fictional and the oral. This paper attempts to trace the oral presence of Hang Tuah which is more varied, colourful, and in effect, more developed than the other two. At present, in Sungai Duyung, Singkep, Riau, Malacca and many places in the Archipelago, there is a wealth of stories about him, his origins, exploits, comrades and death. Many stories of the Sea Sekanaq of West Singkep, Riau claim that he originated from amongst their people. In Bintan, however, where his family found a home, some other famous stories are told of how he met his four friends, and his early relationship with the Bendahara and the Raja of Bintan. Hang Tuah and his family moved to Malacca when the new state became an important and wealthy port. Here, the stories refer to the village of Sungai Duyong in Malacca, its famous well, and his so-called mausoleum in Tanjong Keling. Stories of his life and contribution to the state were composed over time, and are quite different from addition to those of the Sulalat al-Salatin and the Hikayat Hang Tuah. The stories are still being composed and spread through the internet, an instrument of what I call the tertiary orality.
\end{abstract}

Keywords: Hang Tuah, Malay identity, feudal values, origins, orang laut 


\section{INTRODUCTION}

In insular Southeast Asia (including the Peninsula), in what has come to be known as the Malay World, there is a fertile presence of stories about Hang Tuah in the creative imagination of its peoples. These stories may have long been woven into the narratives of the people, as early as the 15th century - when Hang Tuah was the warrior par excellence in the Malacca court, and these narratives continued to be told after his death. These stories, tales and episodes are essentially oral, and seem to be even more dynamic than the written ones that after a while enter into a static form and remain permanently in such a mode. Oral narratives seem to take on a life of their own, like a fertile young seedling growing fast, branching into the ready air of the humid tropical audience, nurtured by composers from outside the royal court and also the (sometimes wild) imagination of others who chose to weave these tales. These stories were further carried into the tradition of the spoken word by these artists and buoyed by their language and tastes.

In the 20th and 21 st centuries, we observe that there are different approaches and interpretations concerning this culture hero. Amongst them are the interpretations of Winstedt (1965), Kassim Ahmad (1964a, 1964b), Josselin de Jong ( 1965), Boris Parnickel (1976), Abu Hassan Sham (1994), Sulastin Sutrisno (1983), V. Braginsky (1990), Mohd Salleh Yaapar (2008) and Muhammad Haji Salleh $(1983,1999,2002)$. Their studies are all based on the famous and daunting, written version of the story, the earliest of which is Leiden's Cod. Or. 1706, and also later versions edited by Sulaiman bin Muhammed Nur and William Shellabear (1908), and finally the most recent by Kassim Ahmad (1964a), which is the most accessible and therefore the most referred to in almost all of these studies. However, the written work itself demands that we return to the history of its composition. As noted by Winstedt (1965:55), most probably these written episodes had their sources in the oral narratives circulating among villages, markets, ports and the court of the time. These were then collected, recreated and transformed with a certain measure of passion and literary enthusiasm, as a written text. Unfortunately, today we have not found the sources of these stories that would have given a time-line for us to trace his life in the greater historical and temporal passage.

My essay hopes to balance Hang Tuah's textual presence in Hikayat Hang Tuah with his oral ones, and better reflect the situation which is current and prior to the 20th century. As suggested earlier, the narrative of Hang 
Tuah is not only still fertile in the collective memory of the race, not only among Malays of the Peninsula but also among the Sumatran, Bruneians, Singaporeans, Javanese and Bugis.

The study of the Hikayat presupposes a return to the history of its composition. Its origins, many agree, are the oral tales from Malacca and Johor. In fact Winstedt (1938/1969:63) who seems to be convinced of these origins, say that:

It is clear that a narrator worked from oral tradition, and to do that he must have lived not so far enough to be able to take liberties, conscious or unconscious, with its history: the interval of the time can hardly have been more than half a century.

He also seems to believe (1969:63) that it was possible that Tun Seri Lanang, the author of the crucial Sulalat al-Salatin himself, picked the stories about Hang Tuah for the purpose of compiling a Malay history. His sources were stories found in the Javanese and Tamil villages of Malacca, before the death of the last Sultan in exile in Kampar, in 1528. I am not very sure that he is correct in being as exact with his dates as there is no evidence of these villages telling these stories. Also, why should they be from Javanese and Tamil villages only, for the Sultan was self-exiled to Pasir Raja and Pekan Tua in Johor. They might well have been the earliest stories which he tapped into. The prologue mentions that he asks his elders for their stories of old Malacca.

However, like Winstedt, Kassim Ahmad (1959) too, believes that the stories collected and recreated in the Hikayat came from the penglipur lara (literally, soother of woes, i.e. storyteller). In his study of the text Abu Hassan Sham (1982: 4-5) too, he found oral elements of the Hikayat, including the journey, battles and love.

It is indeed very likely that some of the episodes in the written version were sourced from these oral stories found across the insular and the peninsular (not only in Malacca) Malay world. These were the kernels of the tales that were duly recreated, combined and given a clear plot and development, i.e. retold in writing with the passion of a literary artist after Hang Tuah had died.

That the Hikayat Hang Tuah was based on early oral stories is a generally accepted thesis. It is quite certain that some episodes have been known to exist, told in the kampung or village, as well as towns and the ports such Malacca, Johor, Kampar and Palembang, among others in Nusantara. Besides, they are found in the upper reaches of the Perak and Pahang rivers. 
Consequently, the belief held by many (based on the ending of the Hikayat Hang Tuah) that he vanished into the forest of the upper reaches of the Perak River, and this surrenders his date of demise to our imagination.

The open ending is intriguing, for although not exactly the same, we notice Alexander the Great is also mentioned as wishing not to be buried. As Robert Bianchi explains http://www.archaeology.org/online/features/ alexander/tomb.html:

Alexander the Great, dying at Babylon on the banks of the Euphrates River in June of 323 B.C., was explicit in his last wish. He wanted his body thrown into the river so that his corpse would disappear. In that way, Alexander reasoned, his survivors might perpetuate the myth that he was whisked off to heaven in order to spend eternity at the side of the god Ammon, who had allegedly fathered him.

By making him vanish from the end of the story the author may consciously wish him to live on in the memory of his race. Or, alternatively, it is possible that Hang Tuah left Malacca because it was plagued with misadministration, corruption and in-fighting, and exiled himself to the forests. Most probably he did so to find peace through meditation, as he had done before in the forests of Majapahit and eastern Malacca when he was hidden away by the Vizier/Bendahara. Many are the questions left unanswered, when the thread of the story is broken, especially those concerning the magical qualities of the hero, his place of birth, death and his special gifts.

As this character lives more in the realm of the oral narrative and the fictional Hikayat, not many have tried to date his birth and death. Furthermore the Hikayat does not help in this matter. About half a millennium after his disappearance, Winstedt, (1965:44), calculated that he must have died close to the end of the 15th century. If Winstedt is right, Hang Tuah died before the fall of Malacca. He has been described as suffering from fevers and headaches, and therefore no longer able to contribute to the battle against the enemy. While this might have been true, the oral stories continued to be told, and he has thus been present for many centuries in the life and consciousness of the Malays and the Nusantara peoples.

This oral life is quite extraordinary and quite different from those of other characters in the Hikayat or in other literary works in Malay or even world literature. Very few indeed are characters of note that live on and on in the consciousness of the people, except perhaps Alexander from Macedonia, who was buried in three places in Egypt (http://www.archaeology.org/online/ 
features/alexander/tomb.html...). Even Hang Tuah himself seems to be needed as a measurement of identity of the Malay race, their achievements and as a guide to the future.

I would now like to trace these oral stories and attempt to describe their most contemporary landscape. Those that we have come to know intimately have been staged as episodes or stories, in different genres and media, including the bangsawan, drama, film, comics, musicals and now anime. More than a cat, he seems to have at least 18 lives, and is at this moment expanding his presence. These are:

1 Primary oral stories in episodes and stories.

2. Sulalat al-Salatin/Sejarah Melayu by Tun Seri Lanang, where he is mentioned 126 times (in the DBP version).

3. Historical texts. Tuhfat al-Nafis by RajaAli Haji, where he is mentioned twice.

4. Epics. Hikayat Hang Tuah (which there are more than 20 editions all over the world).

5. Silat. Stories found among practitioners of silat (Malay martial art, art of self-defence) who believe that the "Silat Hang Tuah" they perform was created by Hang Tuah.

6. Film. The film Hang Tuah (1956) with P. Ramlee in the lead (and directed by Phani Majumdar), another film by the same title (1961, directed by Husain Haniff), and finally Puteri Gunung Ledang (2004, directed by Saw Tiong Hin).

7. Drama. Lakon Sejarah Pahlawan Melayu: Hang Tuah-Hang Jebat, (Syed Alwi bin Sheikh Al-Hadi, 1965), Hang Jebat Menderhaka (Ali Aziz, 1960) Matinya Seorang Pahlawan (Usman Awang, 1968), Jebat (1971) by Dinsman, and another Jebat by Hatta Azad Khan (1987).

8. Comics. Hang Tuah has appeared as a comic strip in local newspapers, such as Utusan Melayu and Utusan Kanak-kanak in the 1950s. It was also in the 1950s that we saw the appearance of the 3-volume narration called Komik Hang Tuah, published by Persatuan Guru Kedah (Kedah Teachers'Association). The artist was Saidin Yahya; it was published in the Jawi script. Next, in 1954, another comic book entitled Komik Hang Tuah di Air Masin (Hang Tuah of the Seas), authored by Ahmad Bakhtiar and edited by K. Bali was printed by Sentosa Store Press, Kuala Pilah . Fifty years separate this work and 
the 2004 Komik Hang Tuah by Dewan Bahasa and Pustaka. To date three instalments have been published.

9. Theatre. Muzikal Puteri Gunung Ledang (2006), directed by Zahim Albakri, and Adlin Aman. Based on the "Puteri Gunung Ledang" (2004) film.

10. Print media-newspapers, magazines, television and advertisements.

11. Forums and interviews on TV, radio, and the newspapers.

12. Studies, recreations of his story, writings since the 1930s that offer interpretations, different perspectives and foci on Hang Tuah, such as Izhab Alang Ismail's Hang Tuah Membuat Jasa (1956), Laksamana Tun Tuah (A. Samad Ahmad), Asas-asas Pembinaan Epik (Noriah Taslim, 1986), Perbandingan Sejarah Melayu dengan Hikayat Hang Tuah (Abu Hassan Sham, 1994) and many others.

13. Short Stories. Sandiwara Hang Tuah (Taufik Ikram Jamil).

14. Poetry. Poems (by Muhammad Haji Salleh, Zurinah Hassan).

15. Novels. Budak Psikik, Gerak Hang Tuah, by Ashadi Zain and Mohd Dat $\mathrm{Hj}$. Molok (2007).

16. Anime (in preparation by Studio Gonzo in Japan in cooperation with Studio Funcel and Malaysia's National Film Development Corporation). The series is known as "Satria-The Warriors of the 7 Elements".

17. Secondary and tertiary oral stories (to be discussed in this paper).

18. Descendants of Hang Tuah.

The long list of secondary and tertiary oral stories, information from practitioners of the silat, various stage and TV drama, and the internet, in my opinion, may be categorized as semi-oral literature (in its wider and more flexible definition), or tertiary orality, i.e. an orality that came in after the era of radio and television. What is certain is the fact that oral and semi-oral is always in dialogue with the written, such as Sulalat al-Salatin and Tuhfat al-Nafis. This has been so since stories were told orally during the times of the hero. All of them were in dialogue not only with the written sources, as we have mentioned, but also oral stories and episodes present at that time.

After several decades of storytelling, recreation and sloughing off old material, some time in the 16th century, these stories may have been gathered by a composer of hikayat and strung into a single plot that is more or less chronological and logical. The stories were indeed numerous and scattered, and therefore needed to be rearranged and restructured into a more attractive and continuous narrative. However, it was only in the 18th century that the 
earliest manuscript was found. On the one hand, it is quite certain that this is just a copy of earlier manuscript or manuscripts that have been destroyed in the passage of time. Though we are not able to date the manuscript exactly, it is quite plausible that in a society that was passionately oral (for literacy was limited to religious scholars, traders, and some of the contemporary thinkers and administrators), a parallel oral narrative has existed along the written one. Thus, although the written age has been around for some centuries, its parallel oral world has continued to be part of the life of the Nusantara peoples.

However, in comparison with the oral, the written works seem dead, stiff and appear to have been stopped in the tracks of their development. According to Ong (1990:81), who refers to Browning's metaphor of the fashion of the times of pressing live flowers in order to preserve them, "the dead flower, once alive, is the psychic equivalent of the verbal text." However, Ong (1990:81) also notices an inherent paradox in this habit of pressing flowers and uses it as a comparison for the written text:

The paradox lies in the fact that the deadness of the text, its removal from the living human life world, its rigid visual fixity, assures its endurance and its potential for being resurrected into limitless living contexts by a potentially infinite number of living readers.

Ong suggests that print kills but, on the other hand, also resurrects the story therein. However, in the Malay World, the probability of its survival is greater, for oral stories tend to have a life of their own, alongside the print and the cyber forms of the narrative. Some still have continued to flower and develop. For instance, in Malaysia, even written works like Hikayat Hang Tuah were still read out aloud to a live audience till the 1940's, for many of those who came to listen were not literate, or if they were unble to obtain the written or the printed copies of the work, and had to depend on readers who owned such. In cases like this, a written work (which might have had oral roots) was transformed into an oral one once again, presented according to the rhythm of the text and assisted by the sonorous voice of the narrator. It is this oral version that continues to live on, bearing flowers and fruits. Some had additions made to them, others were given added personal interpretations of the presenters. Many veered quite far away from the main trunk. When they were repeated, the narrator perhaps even - as Sweeney (1980:37) has said-“composes in performance for his audience," and that composition may have new elements or foci or descriptive words. Of course, there are 
formulae involved here but formulae are only part of the whole process of "composition" and narration. The other parts are the products of the personal talent and creativity of the composer, his language, and also the response of the audience, which often breathed extra life into the performance.

Some parts may be quite "wild" and might have developed by branching far from its trunk. Some other parts might have been updated and given a contemporary element or slant, including new terms and life situations. Thus, we often find that these stories acquire a life of their own according to their needs and situations. They may be free, as youths, following their own preferences. Imagination, contemporary issues and personal difficulties, along with those of the community, often had bearing on the products of composition. The world of the oral composition is exceptional for it is quite free from the world of the original and the first author.

According to Joseph Campbell (1948), a hero should journey through 11 steps in his life, which define his extraordinary character and abilities, from the point of his birth till his death. These steps are useful in our search for the stories concerning Hang Tuah now found in Malaysia and the Archipelago and Thailand, and in categorizing them. These steps are:

1. Birth and extraordinary traits.

2. Invitation to perform meaningful feats.

3. Support, including teachers, amulets and magical tricks.

4. Crossing the threshold, from the worldly to the other world or the real into the fantastic.

5. Tests that define him.

6. His assistants, friends and comrades.

7. The climax or battle that closes his "adventures".

8. Journey of return.

9. Arrival and change.

10. Bringing home wisdom or lessons from the journey for greater good.

11. Return to the original place of departure (home).

Stories created around Hang Tuah in the Archipelago were composed by different authors and retold and recomposed by different narrators and performed by storytellers and performers. Now, in 2012, unfortunately there are no longer professional storytellers conveying the story of this culture hero. Thus, when we enquire about him we are only given bits and fragments of information about summarized episodes, and no longer the stylized and semi-formal performances of earlier times. 
Thus, out of the 11 step or stages that Campbell noted for his mythic hero, only four are of interest to the informants I have interviewed, and discuss in the pages that follow. However, the Hikayat itself, it must be noted, fulfills more of these categories when considered as a complete work. The four stages are:

1. Birth and childhood, with a stress on his special qualities.

2. His supporters who help him in his tests.

3. His assistants and friends--Jebat, Kasturi, Lekir and Lekiu--and the art of silat and magic.

4. His death and descendants.

\section{BIRTH AND CHILDHOOD}

Among all the four stages that these stories or information touches on, perhaps his birth and origins seem to claim the most space and focus. Often, the hero is placed within a certain village, country and race of origin. Thus it is proper that we begin with his place and origins. For the moment, in Malaysia especially, these are the main points of discussion.

If we return, for a moment, to Chapter II of the Hikayat Hang Tuah we are offered a few sentences that describe his place of birth (Epic of Hang Tuah: 2010:35),

The King enquired, "Where are the boys now, and whose children are they? Are they from good families?"

The Bendahara answered, "They are from the Duyung River village. Their families are here seeking refuge. Having sought a place to build their houses, they had come to my village, and are now under my protection. The name of the father is Hang Mahmud, while the son is Hang Tuah; I have now adopted all five boys as my sons and enlisted them as Your Majesty's pages, and duly recorded their names and in the meantime made the acquaintance of their parents."

These details are clear the name of Hang Tuah's village. His original village is not in the kingdom of Bintan, for Bintan is his destination, where they take refuge. It is here that the king has set up a kingdom (administration) to administer the land, and order and peace reigns.

Unfortunately though, the island or Peninsula where the village is found is not named, and the Archipelago where we must seek it has about 

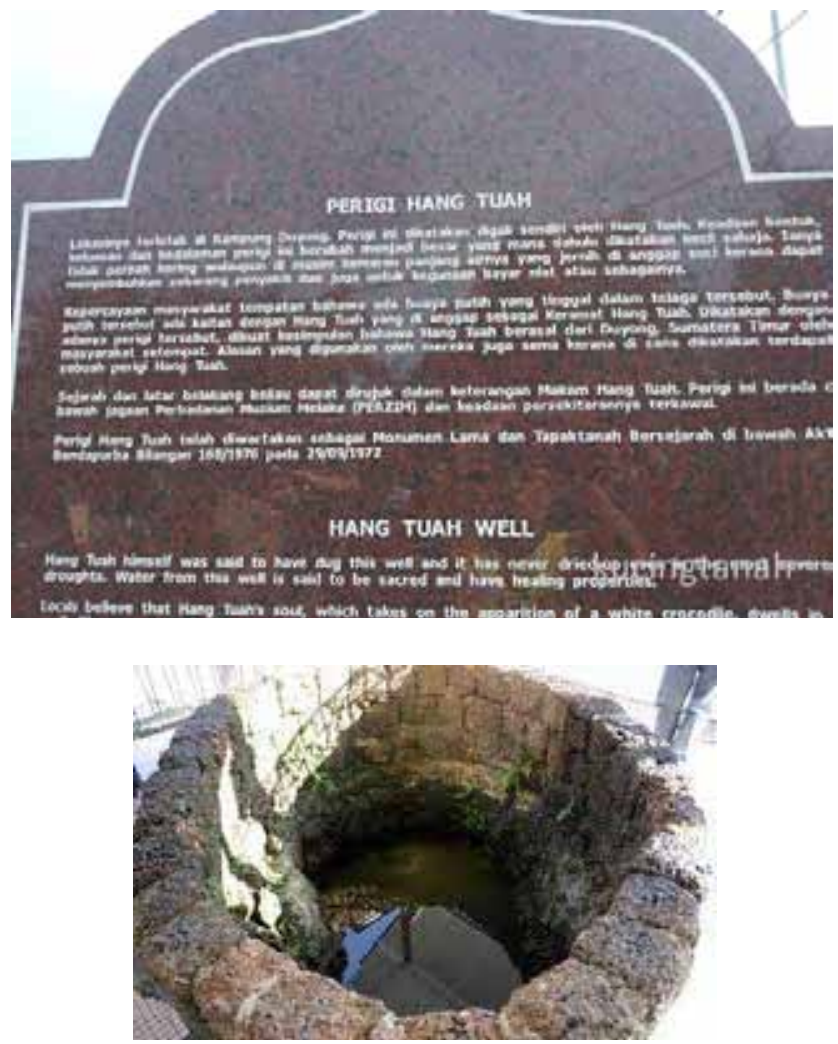

Figure 1 Hang Tuah's Well.

Source: http://www.malacca.ws/attractions/perigi-hang-tuah.htm

20000 islands. Thus our journey to look for it must be on all rivers and river banks, straits, big and small, bearing that name or part of it. Perhaps closest to Bintan would be the islands of southern Riau. This is also the first choice of my search for Sungai Duyung. Secondly, we must seek for it to the south of the Malay Peninsula, in Johor or Pahang, for these states too are not far from Bintan. Thirdly, we look to the Malay states of Sumatra and the north of the Peninsula. To shorten our search we should only look for places with names that have Duyung in it, and that were in existence before the birth of Hang Tuah and their refuge in Bintan, i.e. the first quarter of the 15th century. However, like the stories of Hang Tuah, the history of the villages too has been transmitted orally and also present problems of dating and confirmation. 


\section{Duyung}

Let us seek all villages in the Malay World that contain the word Duyung (Dugong) in its name or which claim to be his birthplace. After a search with the Riau inhabitants, and professors of history and culture, I have been told that there are four in all.

The first is on Batam Island. On this island is Jalan Duyung (Dugong Road) in the district of Sungai Jodoh. Its most famous landmark today is the Novotel Batam. Besides the road there is no Sungai Duyung or Kampung Duyung in Batam. Thus, this first location is of no relevance or importance to our search.

The second, if we spread our search further, to the East of the Peninsula to Terengganu, we may find a village called Kampung Duyong, situated to the north of the city of Kuala Terengganu, and to the west of Jalan Ampuan Bariah, not far from Seberang Takir. Interestingly, there is also a Pulau Duyong Besar close to the estuary of Sungai Terengganu. Could this be the place of Hang Tuah's birth? This is only a village on the bank of the river, and the river is not Sungai Duyong. Also, if we wish to trace the movement of Hang Tuah's family's, then the location of Kampung Duyong in Terengganu is too far from Bintan. Here, too, there is already a kerajaan (kingdom). And furthermore, there is no story of Hang Tuah born here, or any such claims.

The third, Kampung Duyong, in central Malacca. It is but a small village at the junction of Jalan Bukit Katil and Jalan Duyong. The closest river is the Malacca River. There is no Sungai Duyong here. However, of note is the "Perigi Hang Tuah", Hang Tuah's Well. The official information reads that the villagers believe that Hang Tuah participated in the digging of the well, and that "Hang Tuah's soul, which takes on the apparition of a white crocodile, dwells in the well." He hailed from Duyung, eastern Sumatra, and not Malacca itself.

Besides this, there is a mosque known as Masjid Duyong. Thus, if Hang Tuah did take part in the digging of the well, he would have done so during the Malaccan times, when the city was already well-known and he had come from Bintan. He was not born in Kampung Duyong, Malacca, but merely was involved in digging the well there.

My search brought me to a story concerning the origins of Sungai Duyong, reading it in its written version in 366 A Collection of Malaysian Folk Tales, edited by Othman Puteh and Aripin Said (2008:271). The story goes that a school of dugong that lived in the deep waters of the Straits would once in a while swam close to the rocky beaches. It happened that 
one day they swam up the river and liked its cool waters. However, after some time they were eventually bored with this and returned to sea. That was how the village nearby came to be known as Kampung Duyong, the Village of the Dugongs.

Guided by the fact that the place should be known before the inception of the Malacca Sultanate, and that the official plaque does not claim that Hang Tuah was born in Malacca, this Kampung Duyung in Malacca is not a candidate for the warrior's birthplace. Furthermore, if we refer to the episode of Hang Tuah and his four comrades confronting a band of pirates while they were sailing the waters to the south of Temasik or Singapura, the distance is not too far for Orang Laut boys to traverse. However, from Malacca, it is over $350 \mathrm{~km}$, which, I believe, would be beyond them. We may also suppose that the village name was taken from the hero's original village in Singkep. Or, finally, it might just be a coincidence, as dugongs seem to be found in many places of the Archipelago. Our research showed that there are a few places that carry the sea mammal's name.

\section{Singkep in the Lingga Archipelago, Riau}

I sought for Hang Tuah's birthplace in Bakung, Singkep, in the south part of the Riau Archipelago - an island quite big, with streams and a large area of agricultural land. Accompanied by Encik Amran from the Tourist Information Board, and also Professor Suwardi Samin, from Universitas Riau, Pekanbaru. I travelled to Dusun III, Tinjul, Bakung, and stopped in front of the village mosque, on the banks of the river. Here reside mostly the Sekanaq people along with about 100 ethnic Chinese.

The main river is Sungai Tinjul. If one follows it one would reach Sungai Gelam or other villages on its banks. The rivers of western Singkep are quite wide and flow into Sungai Tinjul. In this mangrove world the various types of mangrove and rivers seem to dominate; man is but a diminutive resident. To reach Sungai Duyung we had to use a sekoci, a type of boat which is smaller and narrower than other boats employed by the Sekanaq but more practical for the moving between the mangrove trees.

This is also the world of the Sekanaq. They believe they are the original settlers here, before the coming of the Malays to the island. Now, after half a millennium, the differences between the Sekanaq and the Malays are blurred by assimilation and intermarriage. In fact, they now think of themselves as Malays. As a Barok man declared, "Without the Orang Laut, 


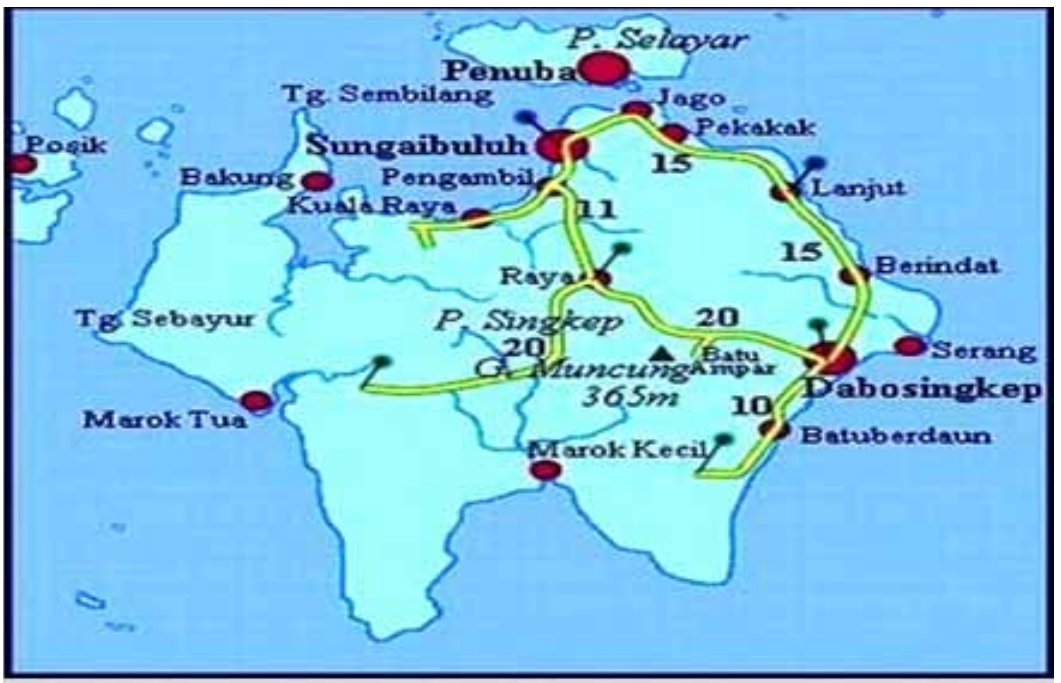

Figure 2 Singkep Island.

Source: http://members.virtualtourist.com/m/p/m/19249a/

there would be no Malays." Many of the Malays of Lingga are descended from the Suku Laut.

The Sekanaq, originally a nomadic sea people, are only one of the six sub-tribes of the Orang Laut - the others are Pusek, Jago, Galang, Baro and Mantang. Over a span of 500 years, the Sekanaq often moved from place to place. In the hierarchy of these sub-tribes, much respect is shown towards the Sekanaq for not only having produced a culture hero but also because they were pivotal in the defence and growth of Seriwijaya, Temasik and also Malacca. Stories woven around Hang Tuah and Sungai Duyung still are being told among the Sekanaq.

As the river narrowed, we were transferred to a smaller boat reminiscent of a dugout but much smaller. Around $11.30 \mathrm{am}$, the water was fast ebbing and the river was critically narrow and shallow. Shortly we entered Sungai Duyung, which is not more than $1 \frac{1 / 2}{2}$ metres wide, as though too small and insignificant to even have a name and contribute to a history of greatness. This is the "Sungai Hang Tuah", believed to be his birthplace.

The short upper reaches of the Sungai Duyung, as can be imagined, are a continuation of the bakau (mangrove forest) and the main rivers, Sungai Tinjul and Sungai Langkap. However, the banks are quite dry, with a forested hill in the background. There are no inhabitants here but there are signs of past habitation - a earthen oven and cleared land. There are also 

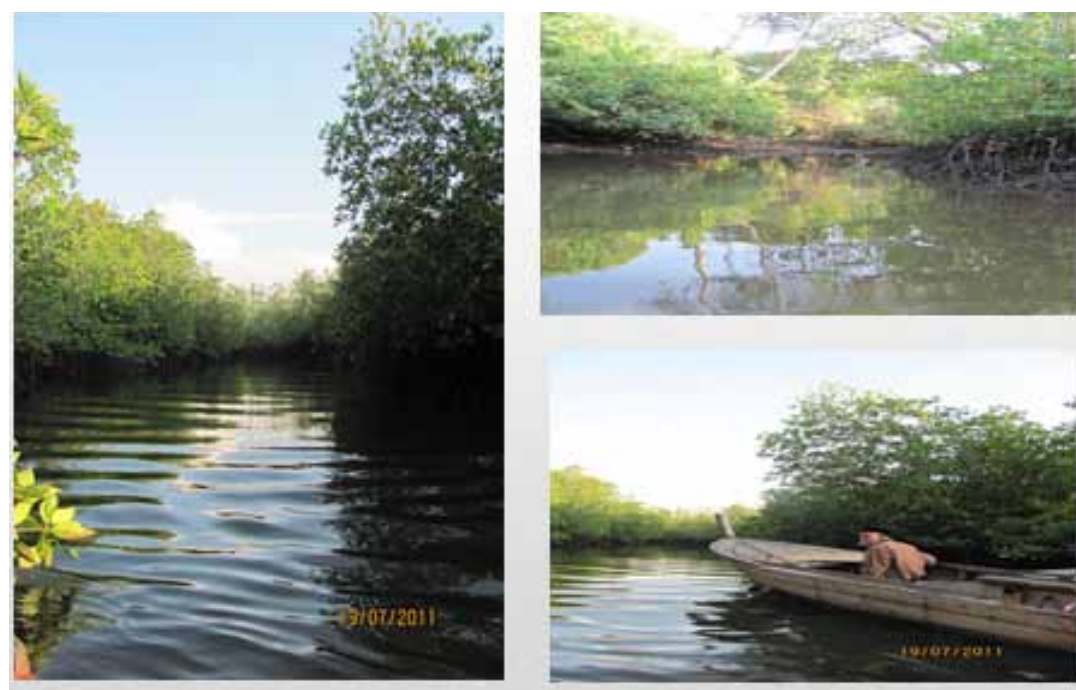

Figure 3 The river bends of Sungai Duyung leading to Hang Tuah's well.

plants that seem to have been planted-kandis (sour mangosteen), cendana (sandalwood) and mangoes. There also forest trees - the getah putih and getah merah (the trees that supplied the gutta percha in days of yore). Far in the distance grow a few coconut trees, tall and old.

At our journey's end, among the trees is a well that has been reconstructed by the Tourist Department. This is the "Perigi Hang Tuah", Hang Tuah's Well. The well water is stagnant during this season, and during ebb tide the water is low and murky. Shaped like a heart, the well is not very shallow. Many come here to seek to fulfil their nazar (vows). According to an elderly resident, prayers are often answered here.

According to the Sekanaq and some Lingga informants, the well is living proof that Hang Tuah and his parents once lived here. Perhaps their house was not far from here. As it was of wood even its poles could no longer be found - a problem for historians in Malaysia and Indonesia. However, the well is more permanent and still offers it water to visitors. The village trees also may be seen as further evidence that a village once stood here. According to an informant, Mohd Jalil bin Tamam, in Penuba Island, (21. 7. 11) it is true that Hang Tuah hailed from the sub-tribe of the Orang Laut, i.e. the Sekanaq of Bakung, because his well is to be found there.

If one rows out from the river in the direction of the sea, one will find a beach of hard rocks. It is said that there are seven wells in all, chiselled 
out of the stone, where Hang Tuah was believed to have meditated, each day at a different well. Now, only two are to be found, the rest may have been eroded by the waves and sand, according to Pak Awang (27.1.2011). So, for him, there is still a need to find the others.

The chronology of his life in the Hikayat does not run parallel to these oral stories but many still repeat them for us, as they seem to be taken as authentic in these islands. This is a distant land but close to the river and the sea - the natural environment of the Sekanaq - that offer fish and other marine products for their consumption or income. Still, it is a hard life, close to a hand-to-mouth existence, or, as the Malays say, kais pagi makan pagi.

This is believed to be Hang Tuah's world, dominated by the river, the sea and the mangroves. If Hang Mahmud desired to find a better living, he had to find it in other places, and perhaps set up a shop or involve himself in trade. And it was a better world that Hang Mahmud and Dang Merdu sought for their family. Here, they could not even send their child to read the Qur'an, for there were no teachers to be found, as described by the Hikayat. All these were push factors that drove them to sail to Bintan, and furthermore there was a good and just king at the helm there, as the Hikayat attests to. In Singkep there might have been a traditional chief, a penghulu or batin, but there was no raja who would protect them from marauders and pirates to allow them to live a peaceful life. In his new Bintan home in the Bendahara's village near Kopak, Hang Mahmud built a shop to sell cakes, sweetmeats and also firewood. It is here that Hang Tuah met his four comrades, as narrated by the Epic (2010:32-33), and saved the Bendahara from an amok.

According to Wan Shamsuddin (2012), Hang Tuah's father was a wood worker. He departed from Bintan after having bought a boat. They went there because the raja was just and good. When they arrived there he was asked his occupation by the raja. When he replied that he was a woodworker, he was asked to gather wood from the forest, while his son might later help the king as a rower in the royal boat.

\section{Bintan}

After surveying all the four sites, i.e. Batam, Terengganu, Malacca and Singkep, it is Sungai Duyung in Singkep that seems to be the most logical place from which Hang Mahmud sailed, if we use the written narrative of Hikayat Hang Tuah as a guide. On the other hand, there is no strong evidence to be gathered at the other three places. They are situated far from Bintan. 
Another thing that we should take into account is the place where the five boys sailed from, in the direction of Singapura. It is also more logical that they sailed from Bintan, northwards. Terengganu and Malacca again are too far away for young boys, even though they might be from the Orang Laut community. There was also no reason why Hang Mahmud should move his family to Malacca, for by then Malacca was not yet established as a kingdom or an international port.

Moreover, if we survey the area around the upper reaches of the Duyung River in Singkep, we may see a few coconut trees that are perhaps evidence of a settlement which has been abandoned. These trees may not have been cultivated by Hang Mahmud but by other generations of settlers who came after them, before they departed for greener pastures. Here, the earnings of the people are meagre, according to Puan Manis bt Bidun (21.7. 11) who moved from there to Bakung. However, according to their inherited oral information and the name of the place itself, this is indeed Hang Tuah's birthplace, before his family heard of the just raja and the prosperity of Bintan and moved to Kampung Bendahara in Kopak.

After returning from Sungai Duyung we stopped at Manis bt Bidun's house. Although this is her birthplace (born 1936), she had lived near Sungai Duyung in her youth. The occupation of the Sekanaq was catching fish and crabs. Like them, she and her family moved from there. She had heard a story told of how Hang Tuah met his four friends in Kopak and went to be tutored by a teacher in Gunung Lengkuas (Galangal Mountain), in Eastern Bintan.

Incidentally, here, too, the typical boat is the lading and sekoci. The former was the type of boat used by the boys when they roamed the seas south of Singapura. The Hikayat (1964a:21) describes it thus: "Hang Tuah anwered, "My father owns a lading, complete with a sail..." Around this area we also hear other stories, besides those already noted earlier. One of them is that Hang Tuah possessed ilmu ghaib, magical knowledge, so that he was able to magically return twice to Sungai Duyung and sharpen his parang (machete) against the rocks on the beach a the western end of the island. It is also told that on this rocky beach there were seven wells in all, and Hang Tuah would meditate each day at a different one, so that he may gain extraordinary strength.

According to Mustafa Kassim (21.7. 2011) further evidence that this is Hang Tuah's place of origin is that there is an old sekoci anchor that can still be seen, though I was not taken there as the water was at an ebb. We were, of course, entering into the world of legend and magic. Hang Tuah 
is said to have left his footprints on the hill behind the well. There used to be traces earlier on but now they can no longer be seen-possibly because of erosion. These stories came in bits and pieces - orally inherited and transmitted information that has become part of the treasury of the Bakung and Duyung areas, and in fact that of the whole of the Lingga Archipelago.

Fifth, there is a claim that Hang Tuah had his origins from the Malays of Deli, while another has it that royal Deli blood flowed in his veins. His real name was Megat Rajuna Ali (http://karimon.wordpress.com/2010/06/01/ hang-tuah/). The blog sources quote another, and unfortunately I am unable to find its real source. This is one of the claims I hear repeated from time to time, not only in the Riau Archipelago but also in Kuala Lumpur and Malacca (refer to the notice board at the Malacca well that says he was from Eastern Sumatra). Wan Shamsuddin bin Wan Omar, of Kota Piring, Bintan, (22.7.11) said that he heard Mohd Yaacob Nori (who died in 1975) confirm the claim that Hang Tuah was of royal Deli descent.

Sixth, still in Riau. Alias Maulud and Syed Muhawi, two elders of the Bintan Bekapur Village in Bintan, asserted that Hang Tuah originated from Sungai Nuyung (notice the name of the river, N(uyung) and not D(uyung), to the western side of the Bintan Mountain. Sungai Nuyung is close to Kopak, the Bendahara's village and not far from Kota Kara, the capital of pre-Malacca Bintan. This seems to be a new story, though it may possibly been told for some time here, where Hang Tuah and his friends grew up and began to serve the king. This story appears to corroborate information found in the Hikayat concerning Hang Mahmud's journey to Bintan. On the other hand we notice that the story does not take into account of other details of the Hikayat which mentions Sungai Duyung and not Sungai Nuyung.

We asked the elders' help to take us to Nuyung. After over an hour's track in the fruit orchards, among very old durian and fruit trees, and along with these the remains of old forest trees, we came to a small clearing, relatively bright because there were not many ancient trees close by. Between two nam-nam fruit trees, are to be found two grave stones, quite ordinary, though I had hoped for markers of a grander scale or style, for example the ornately carved Acehnese ones. I did not find evidence of a 500-year old burial or grave markers; in fact not even of 200 years. Perhaps they were replaced but then why with ordinary ones? So more doubts than answers stayed with us as we walked to a small stream, which is said to be where Tuah's mother, Dang Merdu, used to take her bath and also where she used to do the family's washing. 
Though there are quite a few graves claimed to be Hang Tuah's, yet the stories of the hero refused to be put to rest. The debate rages on. After two main ones in Kuala Lumpur, and Singapore (Berita Harian, 30 April 2012), a report by Chairul Fahmy Hussaini and Ervina Mohd Jamil was published, that quoted John Miksic, a historian of Southeast Asia,

"In my view Hang Tuah did exist. My belief is based on the Okinawa Records (in Japan) that mentions an extraordinary admiral (laksamana), renowned for his feats in the Sultanate of Malacca, around the middle of the 1400's. And these records are reliable for they fill in the void left by the Chinese ones after they severed relations with the outside world, after 1430," he says.

The letters were believed to be sent by the Malaccan Laksamana himself to the king or ruler of Ruru in 1480 and 1481. These letters complained of the misbehaviour of the Ryukyu sailors in Malacca. They are now kept at the Ryukyu Cultural Archives, in Okinawa. The reporters concluded that for Miksic,

Hang Tuah did not only exist, but (is) believed to have his origins in Singapura, i.e. according to these records of 1480 and 1481.

The plot of this search thickens, and in fact opens another important international front in this almost unending search.

Finally, yet another claim has surfaced, this time also from oral sources, but reported by the newspaper, Siasah, that in fact Hang Tuah hailed from Kelantan, the north-eastern state of Peninsular Malaysia. Another blog http://tabutjawi.blogspot.com/2011/11/hang-tuah-hikayat-yang dipertikai. $\mathrm{html}$ notes it in writing. This time it is the turn of Bukit Yong, Pasir Putih, in Kelantan. It is believed that from this village, near the border with Terengganu, Tuah went with his parents to Malacca. The anchorage of this story is Hang Tuah's skill in using the small axe, which is attested to by the Hikayat. Hang Tuah killed amoks just by using this weapon. According to the claim, only Malays of Kelantan and Pattani are adept at using this axe as a weapon. Therein lies the logic of their similarities!

\section{Gresik, Pattani}

The story of Hang Tuah as a traveller who ranged far is already quite established. Thus another story from the northern part of the Peninsula illustrating this point is not surprising. It is narrated that there is a well in 
Gresik in the old Malay state of Pattani, now a part of southern Thailand. This well is believed to have been dug by Hang Tuah himself. The association of the well with this warrior suggests that Hang Tuah's fame-if not the person himself-had reached Pattani.

\section{HANG TUAH ON THE INTERNET}

Studies of oral literature are generally based on spoken poetry and narratives. Often, these narratives are rhythmically spoken or even sung, as is evidenced by the practice of the late "soother of woes", or professional storyteller, Mahmud Wahid, in Pokok Sena, Perlis. Through stories such as "Awang Ada Duit Semua Jadi" (Money Makes the World Go Round), or "Syair Ikan Terubuk" (The Poem of the Toli Shad) or the "Poem of Hilsa", now found mostly in the villages of Bengkalis and also on radio and television at present, employ the "Siti Zubaidah" melody. This oral art is quite alive in these places, and performed by singers or storytellers before live audiences.

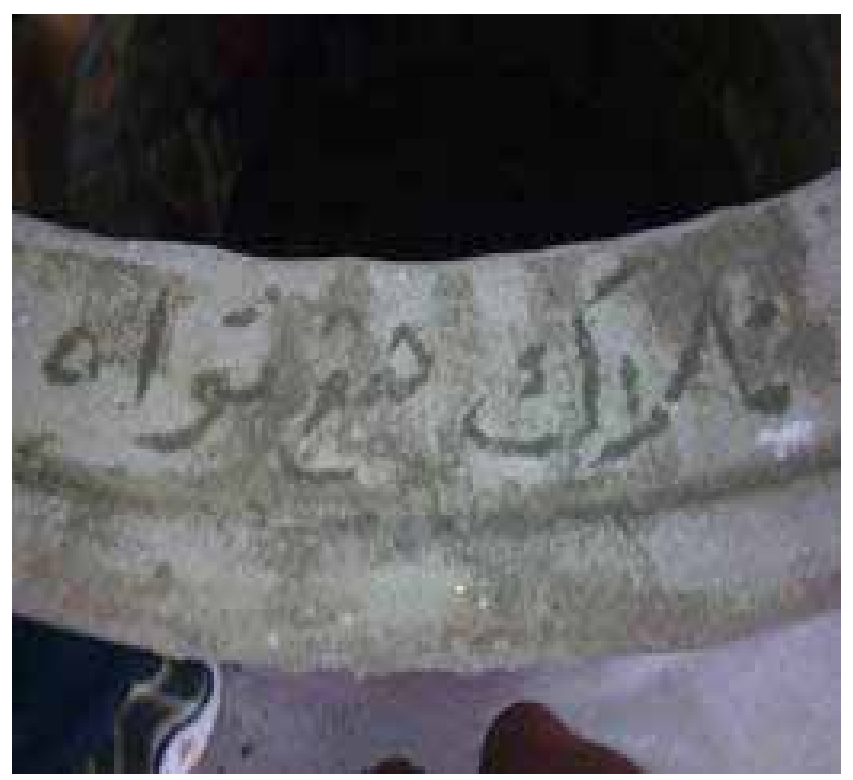

Figure 4 Hang Tuah's well/Telaga Hang Tuah, in Gresik from the image by Patani 0596.jpg. 
The end of the 20th and the beginning of the 21st century present us with a radical new scenario in contemporary communication. Since the 1970s, a shoot of the old media has grown especially fast and, in fact, has overtaken the oral forms. This is the semi-oral medium, supported by the internet. The Internet is not categorized as an oral medium, or spoken before a live audience, though videos on YouTube and some web pages do seem to address listeners. In most cases, it is the written form that makes up the bulk of the information on the Internet.

$\mathrm{Be}$ that as it may, besides the live performances with music in accompaniment, we get the impression that the logic of the information in the discussions offered is indeed close to the oral one-where often-times supporting evidence or necessary steps in a syllogism are bypassed or glossed over, or not presented in full; or their pronouncements are left hanging, waiting for the hearers to fill in the substantial blanks. For example, a website, or a blogger or YouTuber, composes an episode about a very revered hero like Hang Tuah. As we have seen in the claim of Tuah having his origins in Kelantan, we notice that the argument that supports the claim is very weak indeed. Just because he was adept at using the axe, or liked to travel and trade, he must have originated from Kelantan. The story often hurtles along without logic or reality checks. We are supposed to have a prior knowledge of the Hikayat, and the story being told is merely an act of trying to link it to the written narrative. However, the logic behind it is far-fetched, and quite premature in its conclusion. Often enough, when asked to give further details or explain a certain assertion, the informant would just answer, "That's what I have been told." The sources themselves are quite diffused and dim.

Not infrequently, too, daily reality is meshed into some ancient superstitions, mixing two (or more) different worlds. Approaches to what is real and what is believable are also questionable. This, I think, is one of the most prominent features in these oral stories about Hang Tuah. Therefore, the story that is told may on the one hand be based on superstition, and on the other on a modern logic, following the proper steps of a syllogism to arrive at a conclusion. Frequently, however, there is no interest to link the cause to the effect. We are required to approach the story with the belief that Hang Tuah was a superman, mighty, invincible, magical, able to read into the strategies of his enemies, as well as the future. He could travel anywhere he desired without having to sail or ride to his destination. The story that we might hear usually is a part of a larger whole, also based on these premises. A narrative instrument for evidence is to refer to "stories of the people of 
old", which, though not proven, yet produce an aura of a magical or revered reference to the ancestors and the wise people of old. They echo an old-world wisdom, a memory of the race, and need no further evidence.

Also, I notice in reading the blogs and the websites concerning Hang Tuah on the Internet, especially in blogs, that the language employed is much closer to the oral rather than to the written, and does not follow the usual flow of the literary, more official, or more correct written language. All these qualities give them a strong character of the oral rather than the written or the literary, and I am, therefore, of the opinion that they may be better categorized as the semi-oral or as tertiary orality. This is the approach I would like to pursue in this paper, especially in an age when the purely oral is almost at an end in Malaysia. The secondary orality that Ong wrote about is also tapering, and is now being replaced with what I have called tertiary orality.

\section{ETHNIC ORIGINS}

From around April to August 2012, the ethnic origins of Hang Tuah have become a topic of a very imaginative debate, and has caused much consternation among Malaysians. The Malays have for centuries believed (without much opposition) that Hang Tuah hailed from among their people. In the Peninsula, many believe that this great warrior hailed from Malacca (the name of the village and the well are given as proof). If we again refer to the Hikayat, we will be offered a continuation to the first part of the narrative, that Bintan became the capital of a new and emerging Malay kingdom. So we may deduce that Hang Tuah had Malay origins. Moreover, this story was composed and narrated from the perspective of Malacca and the Peninsula. Thus it was concluded that Sungai Duyong in Malacca was his real birthplace. Besides, here is to be found a village called Duyung, complete with a well ascribed to Hang Tuah. We would expect a great kingdom to produce a great warrrior, and as Malacca was influential and prosperous, so the natural bent of the conclusion was towards Malacca as his place of origin. In the meantime, in Pulau Singkep in Riau, as has been shown, there are in existence many other stories that claim him to be from Sungai Duyung in Bakung, in western Singkep. In comparison, there are more tales told of him and his exploits here than in Malacca. Here too legends rise to become myths.

Perhaps we may question Hang Mahmud's name, which is Muslim while he was from the Sekanaq tribe. However, this may be supported by the fact 
that Islam had come to these parts and converted the different sub-tribes. In fact, the sea peoples of the islands would have been in contact with Muslim traders and travellers quite early, being close to Pasai, a hub for the spread of Islam to the whole of Sumatra and the Archipelago.

The Orang Laut were the original settlers of the islands, and became "Malays" when they converted to Islam, and used the Malay language, which has many similarities with their own, and which was instrumental in their daily dealings on the seas and in the ports - the usual process of joining this ethnic community. In fact, this language was the lingua franca for the whole of the Archipelago since the days of the Sriwijaya kingdom, where the Orang Laut played an important role in its expansion, defence and trade (Andaya, 2008); Malay was the instrument in all these functions.

During the Sultanate of Riau-Lingga, from the era of Malacca, around 1450-an to 1911, according to Haji Zainal, "there were Orang Laut who became rowers, carpenters and guards at sea." This description fits well not only with Andaya's picture of the roles of the Orang Laut but also Hang Tuah's father in the Hikayat when Hang Tuah's family arrived in Bintan.

Hang Tuah's mother, Dang Merdu, according to Pak Awang, was the daughter of a religious teacher and imam. This perspective I believe is not too old, and for me it is the first time that a stress is given to the religious belief of Hang Tuah's family, and seems a new addition to the older tales about him. Here, too, the study of the Qur'an and languages among the Sekanaq are given emphasis.

However, a 15th century state in the path of the great ships of the east and the west and the inter-ethnic traffic (like Malacca and Singapura), must of necessity have been flexible and open, and had to adjust itself to the international landscape of trade and also knowledge of languages from many lands, especially the harbour-master and his men, the officers of the palace and the traders themselves. Such a situation would have created a cosmopolitan sense of being and openness to other cultures, even though those involved were Orang Laut. In fact, they would have been among the first people whom by the foreign sailors and traders would encounter, and their help would have been invaluable in navigating the rivers and shallow seas near and not-so-near the port.

Interestingly, perhaps because of this openness during his time and also now, encouraged of course by the internet and a new sense of freedom to express one's emotions and thoughts, Hang Tuah has become the object of claims from various races and tribes. While the Malays have always thought 
him to be Malay, there are several Chinese Malaysians who have come to believe that he and his comrades were Chinese. This is reflected in a very popular blog written titled "Origins of Hang Tuah (and Hang Jebat, Hang Lekiu etc.)" (http://www.yellowbamboohk.com/yellowbamboo/Origins\%20 of $\% 20 \mathrm{Hang} \% 20 \mathrm{Tuah} \% 20 \mathrm{by} \% 20 \mathrm{John} \% 20 \mathrm{Chow} \cdot \mathrm{html}$ ), in which the author, John Chow concludes that the use the title Hang in their names proves that they were of Chinese descent. To add a further note: in Jawi, the original alphabet of the manuscript, the word Hang is spelled as hng, which may be also read as Hing, Heng and Hong, as there were not diacritic marks (still recognizable Chinese family names).

One finds a little more information concerning this title in Wilkinson (1959:394) who defines "Hang" as an "obsolete titular prefix (of which the exact significance is not known) borne by a number of warriors in the days of Mansur Shah and Mahmud I." Winstedt, much later in his An Unbridged Malay-English Dictionary (1970:121), also repeats the information by Wilkinson: an obsolete title + hulubalang. However, Kamus Dewan (1989:401) only offers a short generalized definition: A title for men in history: "Gelaran lelaki zaman dahulu." The Sulalat al-Salatin gives us an earlier and more authentic explanation of the title. (2009:105):

Adapun "Perhangan" ke bawah duli Sultan Mansyur Syah yang setelah sudah pilihan delapan orang, iaitu Hang Jebat dan Hang Kasturi, dan Hang Lekir, dan Hang Lekiu, dan Hang Ali dan Hang Iskandar, dan Hang Hassan, dan Hang Hussin; dan tua-tuanya Tun Bija Sura, menjadi sembilan dengan Hang Tuah.

(There were selected by His Majesty Sultan Mansur Syah eight warriors to join the ranks of "Hang": Hang Jebat, Hang Kasturi, Hang Lekir, Hang Lekiu, Hang Ali, Hang Iskandar, Hang Hassan, and Hang Hussin; and the elder, Tun Bija Sura, made up the ninth with Hang Tuah.)

Sultan Mansyur Syah, after selecting eight young men and an older one created a kind of council of Hangs. There were, as Wilkinson notes, lower ranking officers in the palace. So it was not some title one was born with. All the same, it was used by their descendants.

Recently, however, because of the debate of the origins of Hang Tuah, Professor Nik Hassan Suhaimi, the Chairman of the Association of Archaeologists, Malaysia, offers his own perspective: that the existence of Hang Tuah may be supported by the discovery of the title Hang in Padang Lawas, Sumatra, in the 15th century, and therefore supports the belief that 
the Laksamana or Admiral did serve Malacca during this century (Berita Harian Online, 11 August, 2012).

However, the claim that he was Chinese is a comparatively a new one too, perhaps not more than five years old, and has gone viral on the internet. Confronted with this new declaration, we may read it as another semi-oral assertion; and as a positive wish to be part of Malaysian history that is shared by all the races in the country. The problem with this assertion is that there is no hard evidence to support it - through recorded history or the chronology of Malaccan history. Hang Tuah should predate Malacca, and not be born of Chinese parents who came to Malacca when the city was already an important port in the middle of the 15th century. Ahmad Sarji, in Hang Tuah: Tokoh Epik Nasional (2004:90) calculates that Hang Tuah must have been born in 1444 and died in 1500. What about Hang Jebat, Kasturi, Lekir and Lekiu? Many are the questions that are still unanswered by this claim.

Likewise, the Aslian are also of the opinion that this great warrior was their ancestor. For example, in 1983, Proffesor Alton Becker and I met an Aslian young man in Seremban, Negeri Sembilan. As we were planning to visit Gunung Ledang we asked him if he knew stories about Hang Tuah. His reply came immediately and without hesitation, "Why shouldn't I know him? He is our ancestor." For him and some proud Aslians there is the belief that the blood of this great Laksamana flows in their veins, at least in this tribe in Negeri Sembilan. What is the source of this belief? Is it the last and concluding sentence of the Hikayat that (2010:531):

No longer is Tun Tuah heard of, but he is out there. It is said that Si Tuah did not die, for he is a military chief to all men, and above all a saint. Once there was some news that Tun Tuah resided in the upper reaches of the Perak River, a king to all the forest folks. Even today he is sometime seen by some.

Our study revealed that there are numerous fragments of stories, episodes and pieces of information floating around in the Archipelago at present. Unfortunately, we cannot gather all of these fragments and pieces to fashion a long and continuous narrative - similar or different - to the written one. They are as they are - merely pieces of opinions, sentiment, beliefs and story heard from parents or ancestors. From these we cannot hope to find a unity or continuity of narrative with a proper chronology or at least a literary logic.

Yet another claim still is made by the Tuhfat al-Nafis that Tuah and his friends were presented as gifts to the Sultan of Malacca from the Sultan of the Bugis, as there were no good looking and articulate (baik rupa dan budi 
bahasanya) boys to be found in Malacca. One of these boys of Bugis origin who was presented to the Sultan was named Daeng Mempawah (1979:105). Mempawah was later renamed Hang Tuah. However, this is not a new claim. It is possible that a version of the Sulalat al-Salatin which was recopied in Riau [see Samad Ahmad's transliteration, and also the original manuscript (1979), now stored in the Dewan Bahasa dan Pustaka Library] had some additions made to it. This version describes the mission to Celebes to find the boys. The earliest version of the Sulalat al-Salatin MS 18 (1621) transcribed by Winstedt (1938) and Muhammad (2000), however, has no reference to Tuah as being Bugis. He was described as being from Sungai Duyung.

Hang Tuah himself is introduced in this Malay historical work (Tun Seri Lanang, 2009:88), as being very smart and exceptionally powerful. In his games and duels he would boast that his appropriate adversary would be the Laksamana (Admiral), hence he was known as "Laksamana Hang Tuah".

If we seek other than oral story-tellers or informants and venture into other territories where Hang Tuah has been a great influence, then it is among the silat practitioners that we may find passionate commitment. He is considered as the founding warrior of a certain type of self-defence, i.e. "Silat Hang Tuah" or "Seni Silat Warisan Hulubalang Melaka" (The Silat Art of the Malacca Warriors) that originated from the Laksamana Hang Tuah and his four friends known as "the Warriors of the Malacca Sultanate." (Variasi, Oktober, 2004). Another view is that he is not its originator but rather one of the best in this art form, and therefore it was named after him to honour him and also to lend credence to their discipline. In fact, I would say that it was developed much earlier, perhaps in Sriwijaya, for a great state must have its own soldiers and martial arts for the defence of the country.

With all these claims it comes to us as no surprise that many are quite lost in the tangles of arguments, plots and genealogies, and they are not able to ferret out the true lead. Or are they merely followers of an oral truth, bound heavily in a swath of local beliefs, disseminated through the local cultural practices, ethic myths and imagination? On the other hand, if we wish to anchor ourselves to more solid historical facts, we need perhaps to refer to the work of Leonard Andaya, especially his Leaves of the Same Tree (2008), and the works of some scholars before and after him. The evidence claiming the importance of the Orang Laut in the maritime history of the Archipelago follows the flow of history itself since Sriwijayan times, for it played a pivotal role in this and other kingdoms; and subsequently when the kingdoms of Bintan and Malacca became more established, they accordingly 


\section{MALAY LITERATURE}

supported them. They were the scouts, the guides and the rowers, and the frontline intelligence, before enemies or traders and envoys could reach land (2008:178):

From early times the Orang Laut were employed to perform this vital function, as pilots to guide foreign vessels, and they were strategically positioned not only to guide ships but also to provide early warning of any intended attack from the sea.

As the sea was where they lived, they knew it intimately. In times of war they formed the first line of defence and attack. They were described variously as rowers, serangs, or sailors in the royal or trading vessels, again because they knew the waters more than any other ethnic group.

To continue to trace Hang Tuah's ethnic origins, we need to examine yet another source of information, this time a manuscript now kept in the Malay Manuscript Department, the National Library of Malaysia, in Kuala Lumpur. This work is also entitled Hikayat Hang Tuah but supposedly written by Tun Kula(h) from Duyong, Malacca, and considered to be a rearrangement by Tun Rahim, in 1800. In the summary of the work (Khalid bin Hj Hussin, 2012:2), the origins of Hang Tuah are described as follows:

Both of Tun Tuah's parents, Tun Mahmud and Tun Lela Wati (Dang Merduwati) and their followers sailed from Palembang and when they arrived at Pulau Besar (in the Straits of Malacca)... Tun Lela Wati's father fell sick and died; he was buried on the island. So was his friend, Tun Malakat.

Tun Mahmud was married to Tun Lela Wati. The couple stayed on Pulau Besar for 40 days. Subsequently, they moved to Kampung Sungai, which was also known as Sungai Temu (now officially called Padang Temu) and sailed upstream. They took a rest at Kuala Sungai. By the grace of God, a fish with a human face being appeared at the estuary. This was a dugong. So Tun Mahmud named the village Kampung Duyong. As time progressed, it became prosperous and Tun Mahmud moved again to Balik Bukit, also known as Duyong. However, some of his followers settled in Bukit Ranting, Bukit Katil and Semabok.

At Duyong, Tun Mahmud built a house, and he began to work in the fields. Here, Tun Lela Wati gave birth to a boy, and he was named Tuah. At 10 years of age, Tuah made friends with Jebat, the son of Tun Mamat, Lekir, the son of Tun Baru, Kasturi, the son of Tun Katil and Lekiu, the son of Tun Matang. 
This is a unique version of the Hikayat Hang Tuah. Moreover, it is quite removed from the main storyline of the Hikayat or many of the oral stories that we know. The narrative seems to combine the plot of the Hikayat that we are familiar with with the origins of Kampung Duyong in an attempt to tie the two together. The village in question is Duyong in Malacca, and this then suggests that Hang Tuah did not originate from Sungai Duyung in Singkep but was from Palembang.

Finally, our search leads us to the latest source: that Hang Tuah originated from Kelantan. A report written from information given by locals and which is therefore oral (Siasah, 22-28 Jun, 2012: 4) reads as follows:

According to the belief of a section of the people of Kelantan, in truth Hang Tuah originated from Bukit Yong, near Pasir Puteh, close to the border with the state of Terengganu.

One of the descendants of Tok Janggut (a famous warrior), by the name of Harun Idris, admitted that Hang Tuah's father, Hang Mahmud hailed from Bukit Yong, Kelantan. He heard it from his own father, Idris Awang. Idris, in turn, heard it from his ancestors who claimed that Dang Merdu was descended from Kemboja Malays. Hang Tuah was born in Bukit Bakar, near Machang. From here the family moved to Sungai Duyong, in Malacca. But when he was 10 they again moved to Bintan.

This is also an intriguing claim; however, we must take note that the direction of their move was from Kelantan to Malacca and subsequently to Bintan, while the route offered by the Hikayat is from Sungai Duyung to Bintan and finally to Malacca.

According to Harun, furthermore, Hang Tuah returned to Kelantan to be tutored by Sang Aria Putera, who was locally known as Syeikh Saman. Yet another informant added to this maze of Hang Tuah's origins although he remains unnamed. To him the claim that Hang Tuah from Kelantan supported the similarities in characteristics of Hang Tuah's family members with those of the Kelantanese people: possessing a predisposition to travel, to trade, to use the headband known as semutar, and customary use of the axe. However, he concludes, defensively, "This is the opinion of some Kelantanese. How far the claim is true we should research further."

Oral "truths" or "perkataan orang tua-tua" (narrations of the elders) are often vague and spring from imagination and beliefs. Many of them are quite independent creations, with little overlap between them. Such stories are merely products of the rich and fertile creative minds of the community. 


\section{QUALITIES OF SUPERHERO}

Hang Tuah is often described as being better, stronger, braver and wiser than his comrades, and in fact all the warriors and officers in Malacca, Java and in India. These qualities are said to have emerged or recognized quite early by the chief of Singapura, (2010:25-26),

Among the five, the one named Hang Tuah, I noticed, is of exceptional bearing and manners, and words which came from his mouth were those of a knight, even so he was imbued with decorum and grace...

Traits of chivalry were also noticed quite early in his life: firstly and interestingly enough he was extremely courteous-berbudi bahasa. This quality, no doubt, has in time became his distinguishing trait and endeared him to the king and his vizier.

Secondly, he was extremely skilled with the keris and other weapons, for he was taught their use by the foremost of teachers in Hulu Bintan and after that in Majapahit, the country of magical and renowned warriors. Armed with this skill, it is no surprise that he and his friends were able to overcome formidable adversaries and foes - the first being pirates (whose mastery of the art of defence was quite rudimentary), then Javanese warriors renowned for their prowess and magic, and finally marauders and thieves. Among the Majapahit warriors was Taming Sari and Sang Kertasa. To defeat them was to be able to measure oneself against the best anywhere in the Archipelago. Into this skill is woven courage and the ability to strategize, which is always featured in duels and battles of Hang Tuah and his comrades.

In short, oral stories highlight his courage, and also his ability to anticipate the next move of his adversary, and also his invincibility and magic, though Hang Tuah himself boasts of other qualities that are as important. However, his fighting prowess appeals to young audiences and readers, leading to a more physical level of hero worship amongst them.

Moreover, he is a strategist. Even when Hang Tuah and his friends were young children, they were able to defeat a band of pirates, not because of their strength but because of Hang Tuah's strategic plan of attack. It was also Hang Tuah who led them with great patience and calm against a group of amoks sent by the Javanese King. In Malacca itself, another warrior was sent to create disorder, and Hang Tuah strategically influenced him, therefore first conquering his mind, and then later physically eliminating him. These strategies were also used in India and Siam. 
It is interesting to note that the Hikayat Hang Tuah stresses education. He was an exemplary hero, so he is described early on as having studied under the tutelage of several lebai (religious teachers). Before long, he was able to master 12 languages in all, although still quite young. He also studied religion and the Qur' an. Hang Tuah was, in the definition of his society, an educated man.

As a person he is often shown to be extremely humble, never promoting himself or his interests. Well-known, too, is his own patience and the teaching of others to be patient. We never hear of him boasting of his abilities in words or in action, except to represent king and country. As a leader, we read of his other qualities (in leading small or large groups): that he was a man of exemplary responsibility and sense of duty. He was a total servant to his king, much like a Japanese samurai whose life is to serve his shogun - often beyond the call of duty, and at risk to his own life. These again endeared him to one and all.

The oral stories we hear may also be seen as underlining some of these traits and skills. Thus from the words of Haji Zainal bin King (23.7.11), we hear of him being gentle, "wise in his words, a strong personality, courageous and ... loyal to his king and also never revengeful". These are the qualities and attitudes that Zainal seems to have picked from the stories he has heard around him and other assorted sources to build a fuller picture of Hang Tuah in his mind.

Zainal is of the impression that it was Hang Jebat, who was physically more lawa (handsome) than Hang Tuah. Women were thus more attracted to him. Jebat's voice lends itself to being a better performer or reader of the Hikayat, especially when narrated to a larger audience in the Malaccan days, accompanied by dramatic strategies and an exceptional style.

However, in the final analysis it was the values that Hang Tuah symbolized that were more permanent and influential than those of his friends. In a study of these values, "The Central Values of Hang Tuah, the Malay Hero," (1991:113-44) I attempted to list and discuss them. They are, among others, his physical qualities, his extreme sense of courtesy, humility, total service to king and country, warriorship with responsibility, a well-rounded education, a balanced idea of justice and finally, wisdom.

\section{TUAH'S END/DEMISE}

Hikayat Hang Tuah, our main source of written evidence, does not describe his death but merely says that he has not been heard from and is living among the forest people as their military leader. 
No longer is Tun Tuah heard of but he is out there. It is said Si Tuah did not die, for he is a military chief to all men and above all a saint.

This ending is mysterious, and may be seen to allow a continuation of his presence and influence. It is as a man and a saint that the Hikayat wants us to remember Hang Tuah at the end of this long work. If it is the soul of this warrior that the work wants to keep alive, then it has been very successful, for he was and still is a man and a warrior beyond compare.

In other stories, in an attempt to bind him to "concrete" evidence and certain ethnic origins, he is claimed to have been buried in three mausoleums or graves. The first one has the official seal of the government of Malacca as supporting evidence. This is the mausoleum in Kampung Pengkalan Perigi, Tanjong Keling. It length is almost twice the length of ordinary graves (a symbol of is extraordinary qualities and importance and also the respect bestowed on him by present day Malaysians) and laid with red bricks all around the central section, which is made of concrete.

I saw the mausoleum more than 20 years ago and was not convinced then or now, most importantly because of the Dutch-size red bricks and the new structure of the graves. I also read the possibilities of tourism here, especially since it was no less than the Office of the Chief Minister who supported the project, without the benefit of historical or local studies.

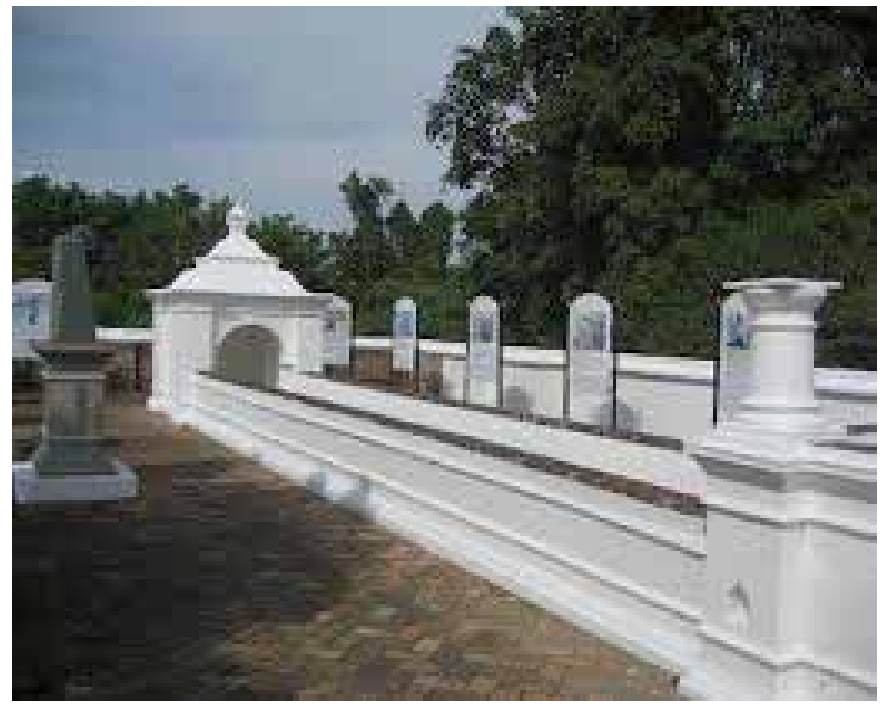

Figure 5 Hang Tuah's mausoleum in Tanjong Keling? Source: Non-datin-diaries. Blogspot.com 
However, according to a blog "The present mausoleum in Tanjong Kling does not belong to Hang Tuah, but a Gujerati scholar of Islam" (http:// sejarahhangtuah.wordpress.com/page/3/).

A visit to Palembang almost 30 years ago took me to another mausoleum near a mosque. This is also claimed to be Hang Tuah's last resting place by the keeper. As I tried to relate the ending of the Hikayat and the flow of Tuah's story, and ferret out a logic from his assertion, he finally confessed that it was the grave of an Arab, and not Hang Tuah's. It seems that he could collect more donations from visitors by claiming it to be Tuah's!

Interestingly in Malacca there are the mausoleums of Hang Jebat, Hang Kasturi, Hang Lekir and Hang Lekiu. However, for these too, we cannot confirm or deny the claims.

Finally, on 23rd May, 2012, with a group of students, and led by Alias bin Maulud and Syed Muhawi, I travelled from Bintan Bekapur village to the direction of Gunung Bintan. In the valley nearby flows Sungai Nuyung (Nuyung River). After about an hour trudging through the ancient fruit orchards with equally ancient durians and forest trees, we arrived at a clearing. All around it were also secondary forest and fruit trees. In the middle of it, walled on three sides, were two grave markers of granite, quite modest. This is said to be where Hang Tuah is buried, i.e. near Sungai Nuyung, a

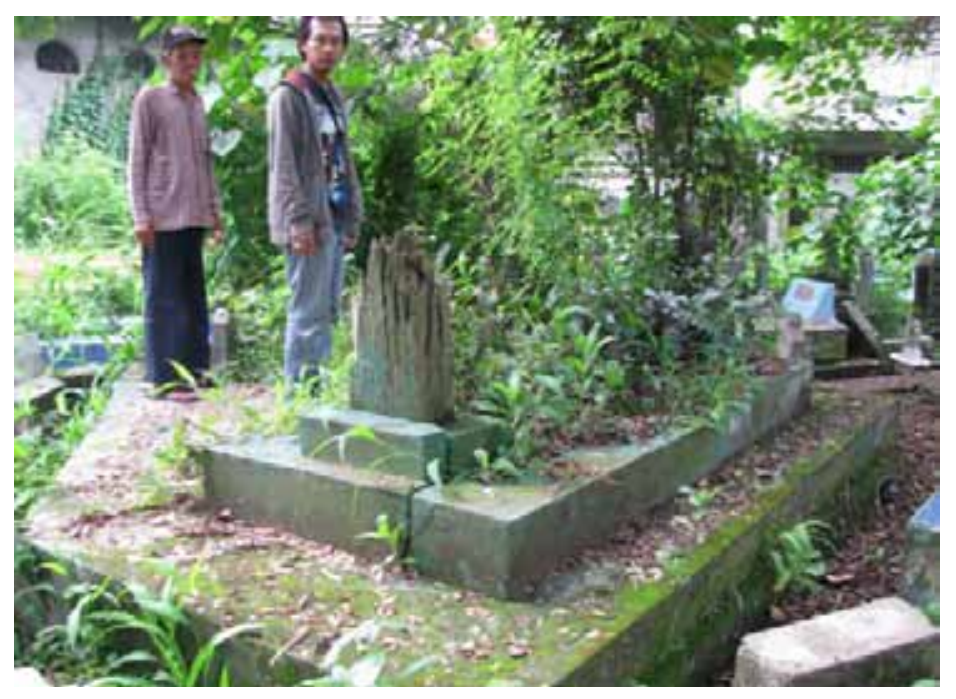

Figure 6 The Palembang cemetery.

Source: http://tabutjawi.blogspot.com/2011/11/. 
name that echoes of Sungai Duyung of the Hikayat and Bakung tales. We were then shown the stream where Tuah's mother is said to have bathed and done her family's washing. The stream is quite overgrown now.

For me both assertions are not very convincing, not by any standard of proof or argument. How he came there is not explained and neither is the grave old enough for the grand contribution of this warrior. It seems as though a story is made up to give Bintan a share in this great narrative of the Malays, not only as the place where he spent his youth (for he grew up here with his comrades) but also his last resting place.

\section{DESCENDANTS OF HANG TUAH}

The Hikayat ends with these words "No longer is Tun Tuah heard of but he is out there. It is said Si Tuah did not die, for he is a military chief to all men and above all a saint."

After his disappearance it is natural for students of his stories to seek his descendants, to link the past with the present, for that is one of the ways of confirming his earlier presence - to ascertain whether he was merely a fictional character or indeed a warrior who lived between 1444 and 1500 . Sulalat al-Salatin names Hang Nadim as his son. However, the lineage fades after that. For hundreds of years, no one we know of, whether in oral or written assertion, has claimed to be his descendant. However, recently, not

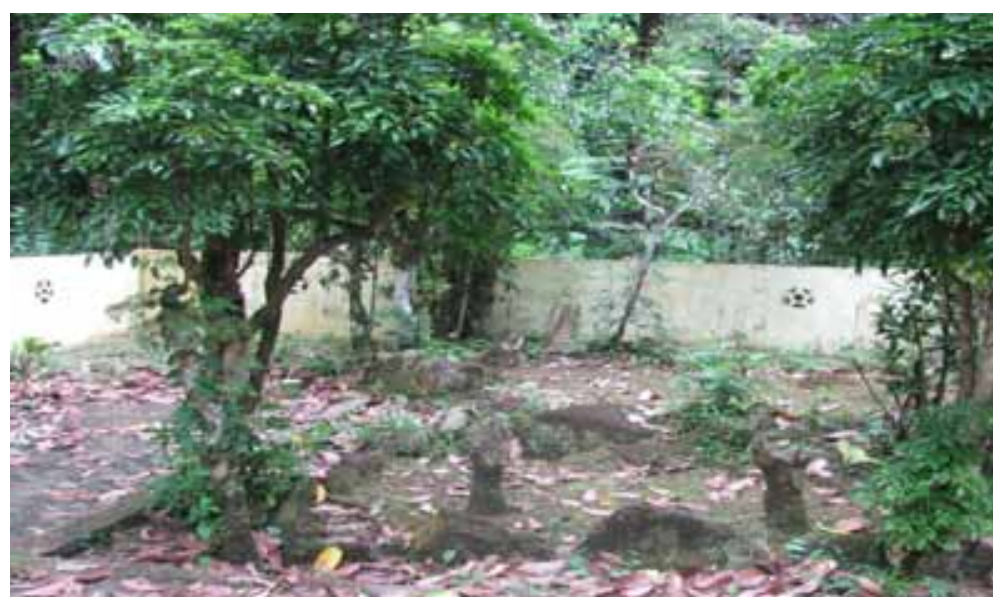

Figure 7 The Sungai Nuyung cemetery . 


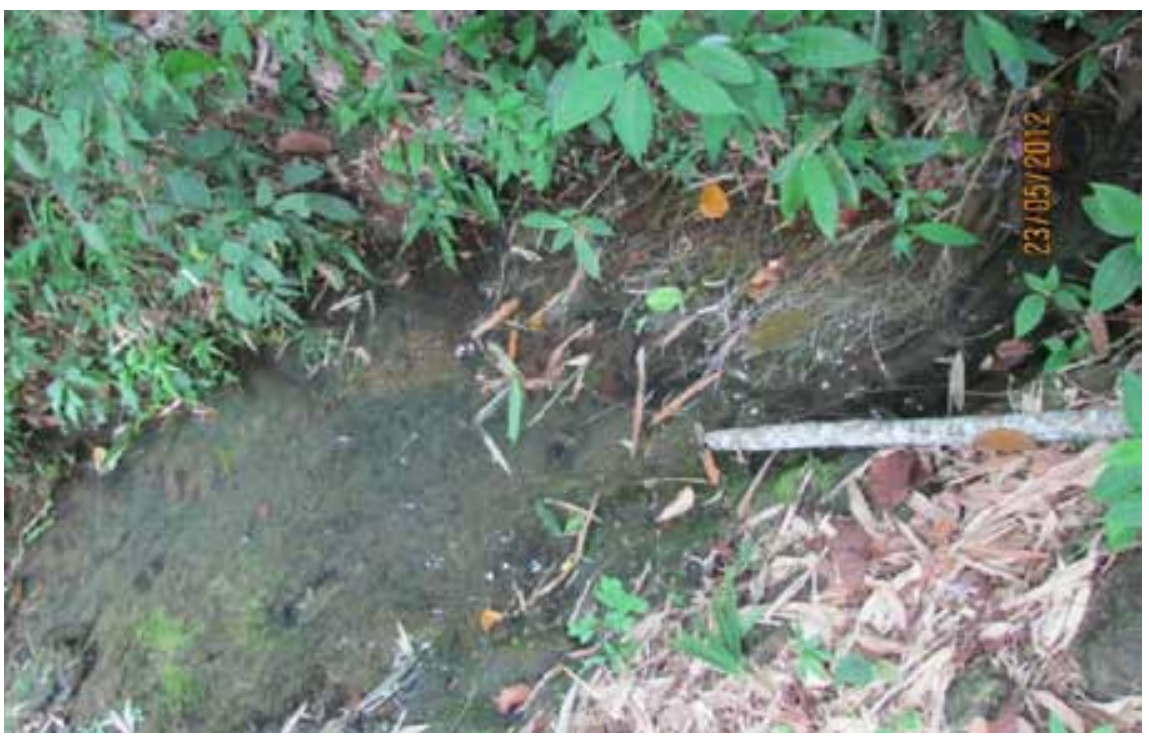

Figure 8 Dang Merdu's bath place.

more than 15 years ago, a movement headed by Khalid bin $\mathrm{Hj} \mathrm{Hussin}$, from the Malay Historical and Heritage Society of Duyong, Malacca (Persatuan Sejarah and Warisan Melayu Duyong), has come forward to state their case and describe their lineage. Their ancestry is based on a note in the Hikayat Hang Tuah, (Tun Kula(h)'s version), and "supported" with a complete genealogy, and seems to be full of information from oral sources.

I have not been able to see this genealogy but it seems that it has been related to the Harian Metro newspaper by Yusri Abdul Malik and Mohd Yatim Latiff. In short, Ismail Mohamed Yaacob, 40, states that he is the 12th generation descendant of Laksamana Hang Tuah. As evidence, he has in safekeeping a pair of gelang tangan (bangles or arm bands) owned by Hang Tuah. The Tun Kula(h) manuscript itself is also given as evidence, as it was supposed to have been written by a relative of Hang Tuah himself, before the former died of his wounds in a battle with the Portuguese. Ismail apparently also has evidence (which was not shown) that Hang Tuah died in Palembang.

\section{A KIND OF CONCLUSION}

The greatest problem in our search for Hang Tuah through the maze of stories and claims, and bits and pieces of information, is the jumble and 
muddle of historical information with stories offered by tabloid newspapers and magazines, oral stories from the past and new ones, two films about the warrior, a musical, and lately the blogs and websites on the internet that are quite wanting in proof. Many are drenched with emotion, racial, tribal and also personal sentiments. In this free-floating world of emotions and passions, these advocates veer quite far from their sources, and often do not stand on the firm ground of evidence and common sense. Now hundreds of blogs (often from oral sources or reasoning) present to us episodes and spontaneous perspectives that have already drowned the scarce historical facts, which were not given much chance of rearing its head. At present Hang Tuah is placed in the hallowed (but on the other hand also profane) grounds of fiction and oral speculation that have no boundaries and may be read, believed or responded to by readers from any country.

Indeed, literature is an inhabitant of this fluid world that flows on the rivers of imagination, preferences, personal and racial values, and not least by tribal sentiments. These emerge as oral or semi-oral (and cyber) narration depending on the talents and passion of their narrators. Their voices flow and merge into other voices, and now are transformed into the letters, sounds and comics, hosted by the all-engrossing Internet. Many, too, have no supporting evidence or concrete proof, even in this age that seeks proof for all things. This is another world with a different sense of what is true.

It is clear that the fictional worlds are plural, liquid and intermingling. We find narration, central characters, imagination and also local or tribal beliefs and superstition. We find historical facts gasping for air from under the mounds of imagination. Yet, above them is a magical world where things do not follow rules of cause-and-effect and therefore lie outside the logic of our daily lives.

As I have mentioned earlier, what confounds the issue is the nature of the information that we receive. Most of this comes to us not in the form of episodes or stories but merely as pieces of episodes or stories and bit of information. However, for a fuller study we require more complete stories, reliable references or logical patterns of argument that can be relied upon. Instead, what we are left with are morsels of information, with no references or explanation, which often come only as stand-alone pronouncements or stories. These are but mere gravel strewn along a road that may not be gathered to form a proper edifice.

In conclusion, we may acknowledge the presence of these stories and information but unfortunately find it difficult to believe them, and thus allow 
them to flow along before us as a phenomenon of oral literature. However, at this point I must remind myself that my task is to collect as many episodes and information as possible about Hang Tuah and his teachers, friends, times and exploits, as well as his disappearance (or demise). It is not my intention to test their truth.

However, the abundance of episodes and information is evidence enough that Hang Tuah still lives on in oral and cyber forms in modern Malaysia, Singapore, Indonesia and Brunei. He is still alive in the conscious and subconscious mind of the inhabitants of the Archipelago. He is significantly relevant to their identity, especially his achievements and the values that were important during his time and which are still being discussed today.

But there are many questions we would like to hear answers to regarding Hang Tuah's incomparable service in Bintan and also Malacca. Those questions are not answered by these oral stories although it is acknowledged that they were not composed to answer our present questions or to deal with the problems of oral composition, beliefs and superstitions.

Many readers of the Hikayat, and of oral stories and cyber narratives, find Hang Tuah to possess good universal values, and to have been an exemplary human being who served king and country beyond the call of duty. He also lived in a Malacca, an empire that spread its tentacles of influence to many states of the Archipelago (Muhammad, 1991). For many Malays, his historical life is not important. Legends and myths are as important and as relevant as stories told 500 years ago to their particular audiences. The stories we hear today are significant to contemporary audiences. The meaning of Hang Tuah is appreciated according to their needs and in some cases is created for the audience's special need or use.

The supporting historical records from the Sulalat al-Salatin, Tuhfat al-Nafis and the archives of Ryukyu seem to point to the fact that Hang Tuah did exist in Malay history. However, this historical fact is now often confused with images and descriptions that are not historical but rather oral products of the imagination. Many creators of these stories project old and ancient beliefs and superstitions into these stories. Others, alarmingly, seem to believe that the truth about Tuah lies in the famous romantic film made in Singapore about half a century ago.

The Malays are not merely superstitious or fabricators of unfounded stories. They have made Hang Tuah the central point of their debate on values, the meaning of being a Malay, of their history and identity. As long as the stories are being told, and new ones composed, the debate on these 


\section{MALAY LITERATURE}

very basic issues will continue and confront them with questions concerning their situation and meaning.

The story of Hang Tuah has been narrated for no less than 500 years. Contemporary developments show that he will be present in the words, imagination and images in the sub-conscious of the Malays for many more years to come, now that he is so strongly represented in the cyber world and in new interpretations such as television, comics and anime.

\section{REFERENCES}

Abu Hassan Sham, 1974. Beberapa Aspek dari Hikayat Hang Tuah. Kuala Lumpur: Utusan Publication \& Distributors Sdn. Bhd.

Abu Hassan Sham, 1993. Pemahaman dan Penghayatan beberapa Aspek Hikayat Hang Tuah. Kuala Lumpur: Masa.

Abu Hassan, 1994. Perbandingan Sejarah Melayu dengan Hikayat Hang Tuah. Kajang: Masa.

Abdul Rahman Napiah, 1988. Tuah-Jebat dalam Drama Melayu: Satu Kajian Intertekstual. Kuala Lumpur: Dewan Bahasa and Pustaka.

Ahmad Sarji b. Abdul Hamid, 2004. Hang Tuah: Tokoh Epik Nasional. Selangor: Pelanduk Publications.

Braginsky, Vladimir, 1990. "Hikayat Hang Tuah: Malay Epic and Muslim Mirror;

Some Considerations on Its Date, Meaning and Structure" in BKI 146. no. 4.

Campbell, Joseph, 1968. The Hero with a Thousand Faces. Princeton: Princeton University Press.

Errington, Shelly, 1975. "A Study of Genre: Meaning and Form in the Malay Hikayat Hang Tuah.” Phd Dissertation, Cornell University, Ithaca.

http://members.virtualtourist.com $/ \mathrm{m} / \mathrm{p} / \mathrm{m} / 19249 \mathrm{a} /$.

http://onnjadi.tripod.com/tuahjebat.html. Accessed on 15 August, 2011

http://sejarahhangtuah.wordpress.com/2010/06/11/makam-hang-tuah-di-palembang/

Accessed on August 2, 2012

http://sejarahhangtuah.wordpress.com/page/3/. Accessed on July, 10, 2011.

http://suhazeli.blogspot.com/2012/02/hang-tuah-sebenarnya-9-bersaudara-new.

html. Accessed on August 21, 2012.

http://tabutjawi.blogspot.com/2011/11/hang-tuah-hikayat-yang-dipertikai.html.

Accessed on August, 27, 2012.

http://www.malacca.ws/attractions/perigi-hang-tuah.htm.

http://www.yellowbamboohk.com/yellowbamboo/Origins\%20of\%20Hang\%20

Tuah\%20by\%20John\%20Chow.html. 
Interview, Alias Maulud, Bintan Bekapur, 23. 05.12

Interview, Manis bt Bidun, Bakung. 27.1. 11.

Interview, Mohd Jail bin Tamam, Pulau Penuba, 21. 7. 11.

Interview, Mustafa Kassim, 21. 7. 2011.

Interview, Pak Awang, Bakung, 27. 1. 11.

Interview, Syed Muhawi, Bintan Bekapur, 23.05.12

Interview, Wan Shamsuddin bin Wan Omar, Kota Piring, 22.7.11

Interview, Zainal Haji King, Pengkalan Dabo, 23.7.11.

Jong, P.E. de Josselin de, "The Rise and Fall of a National Hero," in JMBRAS 38.2:140-55, 1965.

Kassim Ahmad (ed.), 1964a. Hikayat Hang Tuah. Kuala Lumpur: Dewan Bahasa dan Pustaka.

Kassim Ahmad, 1964b. Perwatakan dalam Hikayat Hang Tuah. Kuala Lumpur: Dewan Bahasa dan Pustaka.

Leonard Y. Andaya, 2008. Leaves of the Same Tree: Trade and Ethnicity in the Straits of Melaka. University of Hawaii Press.

Muhammad Haji Salleh, 1991. "Central Values of the Malay Hero: Hang Tuah" in

Yang Empunya Cerita: The Mind of the Malay Author. Kuala Lumpur: Dewan Bahasa and Pustaka.

Muhammad Haji Salleh, 1993. 1994. "Romping Around in Epical Space: Making Room for Hang Tuah.” Working Paper presented at the VTCZOA Seminar, Leiden University.

Muhammad Haji Salleh, 1999. "Mendialog Wira: Hujah di sebalik Kata” in Menyeberang Sejarah. Kuala Lumpur: Dewan Bahasa and Pustaka.

Non-datin-diaries. Blogspot.com.

Othman Puteh \& Aripin Said, 2008. 366 A Collection of Malaysian Folk Tales.

Kuala Lumpur: Utusan Publication \& Distributors.

Parnickel, R. B., 1976. “An Epic Hero and an Epic Traitor," in the Hikayat Hang Tuah. BKI. 132, 4:403-17.

Robert Bianchi, (ttp:/www.archaeology.org/online/features/alexander/tomb.html) Accessed on August, 25, 2012.

Siasah. 22 -28 June 2012, p.4.

Sulastin Sutrisno, 1983. Hikayat Hang Tuah: Analisa Struktur and Fungsi. Yogyakarta, Gajah Mada University Press.

Sweeney, Amin, 1980. Authors and Audiences. Berkeley, Dept. of South and Southeast Asia, University of California, Berkeley.

Syed Alwi al-Hadi, 1965. Pahlawan Melayu: Hang Tuah-Hang Jebat. Singapore:

Malaysia Publications. 
MALAY LITERATURE

T. Iskandar, 1995. Kesusasteraan Klasik Melayu Sepanjang Abad. Brunei: Privately Published.Variasi, October, 2004.

Utusan Online 2012-01-20: 20/01/2012 5:0. Accessed on August, 23, 2012.

Wilkinson, R.J., 1903. A Malay-Engslih Dictory. London: Kelly and Welsh.

Winstedt, Richard, 1965. A History of Classical Malay Literature. Kuala Lumpur: Oxford University Press.

Winstedt, Richard, 1966. An Unabridged Malay-English Dictionary. Kuala Lumpur: Marican. 